\title{
An Analysis of the Difficulty in Solving Algebra of the Students of Junior High School in Bantul Regency
}

\author{
Lana Sugiarti ${ }^{1}$ and Karyati ${ }^{2}$ \\ \{lanasugiarti09@gmail.com\} \\ Universitas Katolik Indonesia Santu Paulus Ruteng ${ }^{1}$, Universitas Negeri Yogyakarta ${ }^{2}$
}

\begin{abstract}
This survey research aims to determine the types of student difficulties of junior high school student in Bantul Regency in solving algebraic questions. The subjects of this research consisted of 335 grade VIII students of junior high school in Bantul Regency who came from 12 schools with high, medium and low strata categories. Data collection was carried out by means of tests and interviews to track the types of difficulties, namely difficulties in facts, concepts, principles, skills and causal factors. The results showed that the principal difficulty was $56,47 \%$, the conceptual difficulty was $52,24 \%$, the skill difficulty was $49,15 \%$ and the factual difficulty was $27,66 \%$. The factors that cause difficulties, namely students are not able to (1) write symbols and write what is known from the question, (2) understand the concept of problem-solving techniques and manipulate algebraic forms and methods of elimination and substitution, (3) combine several concepts and apply the formula used, (4) solve ser problems, equation lines, relations and functions, basic mathematical operations and determine the final answer.
\end{abstract}

Keywords: Concepts; Difficulties; Facts; Principles; Skills

\section{Introduction}

Mathematics is a subject that always exists at every level of education. Starting from basic education to higher education, there is always something to do with studying mathematics. Mathematics is a part of science whose applied and reasoning aspects are widely used in various fields, especially technology [1]. Mathematics is a science that is close to everyday life. In daily activities, mathematics cannot be separated. For example, in buying and selling transactions in the market, in the rules for taking medicine from a doctor, in measuring buildings, and so on. That means that mathematics is something we need in everyday life. Mathematics is also concerned with geometry, algebra, trigonometry, arithmetic, and so on. Mathematics is very important in facing advances in science and technology [2].

So, an increase in thinking skills in mathematics is very necessary because the need for understanding and use of mathematics in life and in the world of work is getting bigger and bigger [3]. Junior high school students for example, still find many students who find it difficult to do math problems. Many of them argue that there is certain material in mathematics that is difficult to understand. NCTM [4] says that mathematical competence opens the door to a productive future. So that mathematics is an important science to learn in the world of education.

According to [5] in learning mathematics there are two objects obtained by students, namely direct objects and indirect objects. Direct objects consist of facts, concepts, skills, and principles. Begle [6] states that the objectives or objects of mathematics study are facts, concepts, 
operations, and principles. Facts usually include terms (names), notations (symbols / symbols), and so on. Meanwhile, a concept is an abstract idea that allows grouping objects into examples and non-examples. Skills related to the student's ability to provide answers and principles can be a combination of concepts and facts. After students learn mathematics, students are expected to obtain these four things. This is in line with [7] that the difficulties experienced by students are classified into factual difficulties, conceptual difficulties, operational difficulties and principal difficulties.

Soedjadi [8] says that the difficulties experienced by students will allow errors to occur when answering test questions. As explained by Soedjadi, the mistakes made by students in answering questions on algebraic material are evidence of the difficulties experienced by students in this material. Students' difficulties in solving algebraic questions can be seen from the mistakes made by students in answering the algebraic material questions. This is in line with what Jupri [9] said that difficulties lead to obstacles that cause mistakes made by students when solving algebraic problems. In this regard, it is said that errors in solving math problems often occur both in writing and orally [10].

Based on the BSNP report regarding the average absorption capacity of the 2017 National Examination in Bantul Regency on algebra material still needs attention. The suboptimal results were also made possible by the difficulty of students in understanding the material or in solving algebraic problems. In addition, there are many things that cause students to have difficulty solving problems related to algebra. These student difficulties are also related to students' selfability. Learning difficulties refer to barriers that limit access to participation and outcomes in a lesson plan. Yoong (2000) in [11] states there are five problems in learning mathematics, in fact these five different problems can be shown through the same mistakes by students. These problems are attaching own meanings, incomplete or fuzzy thinking, mix up the rules, salient features, and a conformist attitude.

Many factors influence students' difficulties in solving math problems, including internal (students) and external (teachers, parents, school, community, and so on). However, in this case the two factors will be examined. Suryabrata [12] revealed that internal factors are physiological and psychological (for example: intelligence, motivation, achievement, and cognitive abilities). External factors are environmental and instrumental factors (for example: schools, teachers, curriculum, and learning models). Student difficulties can also come from mistakes made by students in understanding the perspectives made by their teachers in the presentation and understanding of word problems, making a plan, and describing related vocabulary [13]. So, the focus in this study is to analyze the types of errors made by students in solving algebra problems.

\section{Methodology}

This research is a survey research with qualitative and quantitative approaches. This study also aims to describe the difficulties of students of Junior High School in Bantul Regency in solving problems related to algebra in the types of difficulties in facts, concepts, principles and skills. A qualitative approach is used to determine the types of student difficulties and the factors that cause students to experience difficulties in solving algebraic problems. To clarify the difficulties experienced by students, interviews were conducted with research subjects. This research was conducted in junior high school in Bantul Regency, amounting to 48 schools, which were categorized into high, medium, and low categories. The time of the research was carried out in December 2018-January 2019. Sampling was done by using a stratified 
proportional random sampling technique. This research was conducted by providing an algebraic difficulty test and interviews. This is done to students who are the subject of research. To determine the sample size used, the first step is to register all state junior high schools in Bantul Regency. After that, the next thing to do is to determine the school strata based on the average score of the Mathematics National Examination. The grouping of school strata is divided into three categories, namely high, medium, and low.

The data required in this study are used to determine the validity, effectiveness, and practicality of the product. To get the validity of the data, expert validators are needed. The validators in this study are 2 people who have expertise in their fields. The validated algebraic test instrument was used to collect research data.

Table 1. Criteria for Student Difficulties in Complete Algebra Problems

\begin{tabular}{cl}
\hline Interval & Criteria \\
\hline$X>M i+1,5 S i$ & Very high \\
$M i+0,5 S i<X \leq M i+1,5 S i$ & High \\
$M i-0,5 S i<X \leq M i+0,5 S i$ & Moderate \\
$M i-1,5 S i<X \leq M i-0,5 S i$ & Low \\
$X>M i-1,5 S i$ & Very low \\
\hline
\end{tabular}

\section{Result and Discussion}

Information was obtained about student difficulty scores related to junior high school algebra based on the average results of students' answers in solving 6 questions regarding algebraic difficulties. Each school stratum has a different average. This shows the ability of different students in solving problems related to algebra. The algebra-related difficulty test score at high strata is in the medium criteria with an average of $48.62 \%$ so it can be concluded that students at high strata have a moderate level of algebraic difficulty. The highest score achieved by students is 47 and the lowest score is 30 .

Schools with moderate strata are in the high category with an average of $63.92 \%$ so that it can be concluded that students at the strata are experiencing high category algebra difficulties. The highest score achieved by students was 38 and the lowest score was 26 . Meanwhile, the average result obtained from schools with low strata was $77.76 \%$. The highest score achieved by students is 32 and the lowest score is 14 . Therefore, it can be concluded that students at low strata experience the highest difficulty in solving algebra-related questions.

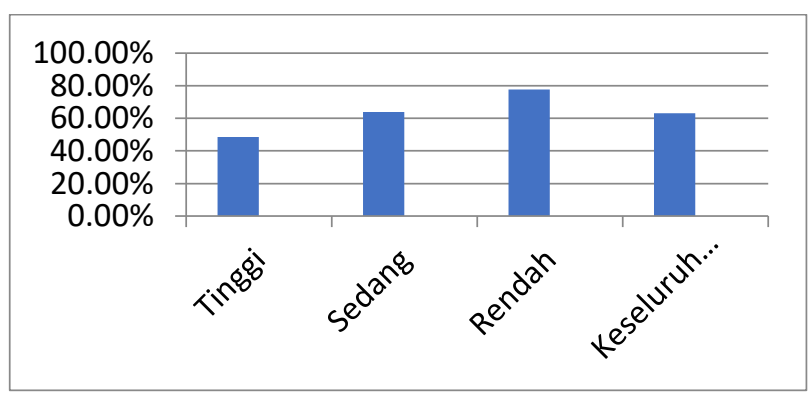

Fig 1. Score of Student Difficulties in Solving Algebra Problems 
Based on the results of tests and interviews, the types of student difficulties in solving the 6 test questions were determined based on the competencies achieved in mathematics. The types of difficulties are generally presented in Table 2 .

Table 2. Answers 335 Students According to Type of Difficulty

\begin{tabular}{llll}
\hline Types of Difficulty & Many Errors & Many Answers & \% \\
\hline Fact Difficulty & 556 & 2010 & 27,66 \\
Concept Difficulty & 1050 & 2010 & 52,24 \\
Principle Difficulty & 1135 & 2010 & 56,47 \\
Skill Difficulty & 988 & 2010 & 49,15 \\
\hline
\end{tabular}

The factors that cause students to experience difficulties also vary. Factors that cause difficulty in solving problems include students unable to draw the Venn diagram correctly, students cannot determine the slices of the three sets, students do not master the formula, students are wrong in applying basic mathematical operations, students are wrong in manipulating algebraic forms and students are wrong in determine the completion steps. Errors in working on algebra questions were made by students forgot the steps in working on the questions and were less thorough.

\section{Conclusion}

The most dominant types of difficulties experienced by junior high school students in solving algebraic problems in Bantul Regency in terms of the object of study are: (1) difficulty applying principles, (2) difficulty understanding concepts, (3) difficulties in skills, and (4) difficulties. using facts. So that the most dominant type of error made by students is applying principles. Factors related to the concepts found in the study, namely students do not understand the concepts in solving techniques, determining slices, determining square elements, solving systematics, manipulating algebraic forms, and solving steps as well as elimination and substitution methods.

\section{Recommendation}

Based on the results of this study, the recommendation is that teachers are able to find more types of student errors in working on algebra problems or other problems in the field of mathematics.

\section{Acknowledgments}

The author would like to thank the Universitas Katolik Indonesia Santu Paulus Ruteng who has facilitated this article to be presented at international seminars and to all parties who have supported data collection during the research. Thanks also to the principal and teachers where data collection was carried out and to the Bantul district education office.

\section{References}

[1] Mahmud, D. A. (2014). Keefektifan Model Pembelajaran ISK dan Ditinjau dari motivasi, Sikap, dan Kemampuan Komunikasi Matematis.Jurnal Riset Pendidikan Matematika, 1(2), 188-201. 
[2] Wahyuni, A. (2014). Perbandingan Keefektifan Pembelajaran Cooperative Learning Type STAD dan Type TPS pada Pembelajaran Bangun Ruang Siswa SMP. Jurnal Riset Pendidikan Matematika, 1(2), 164-175.

[3] Lahinda, Y. (2015). Analisis Proses Pemecahan Masalah Matematika Siswa Sekolah Menengah Pertama. Jurnal Riset Pendidikan Matematika, 2(1), 148-161.

[4] National Council of Teacher Mathematics. (2000). Principles and Standards for School Mathematics. Reston, Virginia: NCTM.

[5] Suherman, E. (2003). Strategi Pembelajaran Matematika Kontemporer (Edisi Revisi). Bandung: JICA IMSTEP.

[6] Hudojo, H. (2005). Pengembangan Kurikulum dan Pembelajaran Matematika. Malang: UM Press.

[7] Wati, S., et al. (2018). Students' Difficulties in Solving Linear Equation Problems. Journal of Physics, 983, 1-6.

[8] Soedjadi, R. (1996). Kiat Pendidikan Matematika di Indonesia. Jakarta: Departemen Pendidikan dan Kebudayaan.

[9] Al Jupri, \& Drijvers, P. (2016). Student Difficulties in Mathematizing Word Problems in Algebra. Eurasia Journal of Mathematics, Science and Technology Education, 12(9), 2481-2502.

[10] Zakaria, E., et al. (2010). Analysis of Students' Error in Learning of Quadratic Equations. International Education Studies, 3(3), 105-110.

[11] Novferma, N. (2016). Analisis Kesulitan dan Self-Efficacy Siswa SMP dalam Pemecahan Masalah Matematika Berbentuk Soal Cerita. Jurnal Riset Pendidikan Matematika, 3(1), 76-87.

[12] Suryabrata, S. (2014). Psikologi Pendidikan. Jakarta: PT RajaGrafindo Persada.

[13] Azis. (2015). Analisis Kesulitan Kognitif dan Masalah Afektif Siswa SMA dalam Belajar Matematika Menghadapi Ujian Nasional. Jurnal Riset Pendidikan Matematika, 2(2), 162-174. 